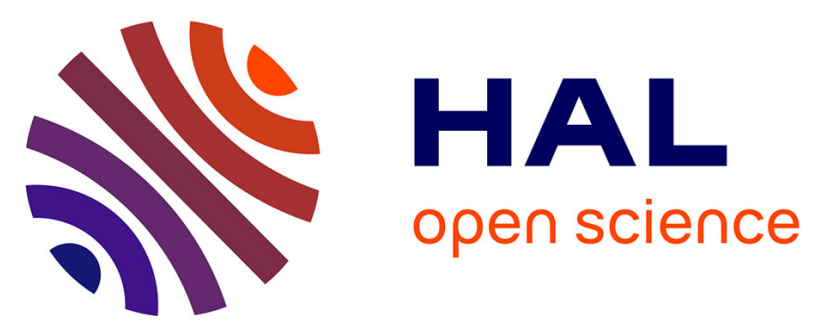

\title{
Responsiveness to Change of 5-point MRC scale, Endurance and Functional Evaluation for Assessing Myositis in Daily Clinical Practice
}

Océane Landon-Cardinal, Hervé Devilliers, Nathalie Chavarot, Kuberaka Mariampillai, Aude Rigolet, Baptiste Hervier, Yves Allenbach, Olivier

Benveniste

\section{To cite this version:}

Océane Landon-Cardinal, Hervé Devilliers, Nathalie Chavarot, Kuberaka Mariampillai, Aude Rigolet, et al.. Responsiveness to Change of 5-point MRC scale, Endurance and Functional Evaluation for Assessing Myositis in Daily Clinical Practice. Journal of Neuromuscular Diseases, 2019, 6 (1), pp.99107. 10.3233/JND-180358 . hal-03523534

\section{HAL Id: hal-03523534 \\ https://hal.sorbonne-universite.fr/hal-03523534}

Submitted on 12 Jan 2022

HAL is a multi-disciplinary open access archive for the deposit and dissemination of scientific research documents, whether they are published or not. The documents may come from teaching and research institutions in France or abroad, or from public or private research centers.
L'archive ouverte pluridisciplinaire HAL, est destinée au dépôt et à la diffusion de documents scientifiques de niveau recherche, publiés ou non, émanant des établissements d'enseignement et de recherche français ou étrangers, des laboratoires publics ou privés. 


\title{
Responsiveness to Change of 5-point MRC scale, Endurance and Functional Evaluation for Assessing Myositis in Daily Clinical Practice
}

\author{
Océane Landon-Cardinal ${ }^{\mathrm{a}, 1, *}$, Hervé Devilliers ${ }^{\mathrm{b}, 1}$, Nathalie Chavarot $^{\mathrm{a}}$, Kuberaka Mariampillai ${ }^{\mathrm{a}}$, \\ Aude Rigolet ${ }^{\mathrm{a}}$, Baptiste Hervier ${ }^{\mathrm{a}}$, Yves Allenbach ${ }^{\mathrm{a}}$ and Olivier Benveniste ${ }^{\mathrm{a}}$ \\ ${ }^{a}$ Department of Internal Medicine and Clinical Immunology, National Reference Center of Neuromuscular \\ disorders, Pitié-Salpêtrière University Hospital, Sorbonne Université, Paris, France \\ ${ }^{\mathrm{b}}$ Department of Internal Medicine and Systemic Diseases, Dijon University Hospital, Dijon, France
}

\begin{abstract}
.
Background: Manual muscle testing has been widely used for the evaluation of muscle strength in myositis, yet less attention has been devoted to the evaluation of muscle function and endurance.

Objective: Our objective was therefore to compare the responsiveness to change of muscle strength, endurance and functional testing following induction therapy for severe myositis flare (requiring high-dose corticosteroids and combined immunotherapy) in patients with a diagnosis of dermatomyositis, immune-mediated necrotizing myopathy, or overlap myositis.

Methods: Muscle status was assessed at baseline and after mean $6.4 \pm 1.9$ months, using the MRC-5 scale, along with endurance (Barre and Mingazzini maneuvers) and functional evaluation (e.g. chair rise) and responsiveness to change was evaluated using the Standardized Response Mean (SRM) and Standardized Mean Difference.

Results: Among the 49 patients included, the strongest responsiveness to change was observed in the muscle testing of the psoas and deltoids (SRM: 1.23 and 1.16, respectively). Noticeably, endurance testing also demonstrated strong responsiveness (SRM: 1.05 and 0.96, respectively), compensating for the poor discriminatory ability of muscle testing and permitting to overcome its ceiling effect.

Conclusion: Functional and endurance testing provide simple and reliable measures complementing the testing of select proximal muscle groups to evaluate responsiveness to intervention in myositis patients in daily clinical practice. Interest of functional and endurance testing should be evaluated prospectively as outcome measures in myositis clinical trials.
\end{abstract}

Keywords: Idiopathic inflammatory myopathies, myositis, manual muscle testing, responsiveness, endurance, functional evaluation, outcome measures

\footnotetext{
${ }^{1}$ These authors contributed equally to this work.

*Correspondence to: Océane Landon-Cardinal, Department of Internal Medicine and Clinical Immunology,
}

Pitié-Salpêtrière University Hospital, 47-83 Boulevard de l'Hôpital, 75013 Paris, France. Fax: +33 1421610 58; E-mail: o.landoncardinal@gmail.com. 


\section{ABBREVIATIONS}

\begin{tabular}{|c|c|}
\hline MMT & manual muscle testing \\
\hline IMACS & $\begin{array}{l}\text { International Myositis Assessment and } \\
\text { Clinical Studies group }\end{array}$ \\
\hline MMS & Myasthenic Muscle Score \\
\hline CMAS & Childhood Myositis Assessment Scale \\
\hline $\mathrm{DM}$ & dermatomyositis \\
\hline IMNM & immune-mediated necrotizing myopathy \\
\hline $\mathrm{OM}$ & overlap myositis \\
\hline ASS & antisynthetase syndrome \\
\hline CTD & connective tissue disease \\
\hline $\mathrm{CS}$ & corticosteroids \\
\hline IVIg & intravenous immunoglobulin \\
\hline IBM & inclusion-body myositis \\
\hline MRC & Medical Research Council \\
\hline SRM & Standardized Response Mean \\
\hline SMD & Standardized Mean Difference \\
\hline MSA & myositis-specific antibody \\
\hline MAA & myositis-associated antibody \\
\hline CK & creatine kinase \\
\hline MTX & methotrexate \\
\hline AZA & azathioprine \\
\hline PRINTO & $\begin{array}{l}\text { Pediatric Rheumatology Clinical Trials } \\
\text { Organization }\end{array}$ \\
\hline
\end{tabular}

\section{INTRODUCTION}

Manual muscle testing (MMT) has been widely used for the evaluation of muscle strength in myositis [1]. Traditionally, MMT has been assessed using 5point MMT scales, including the Medical Research Council Scale (MRC-5) [2, 3]. Kendall et al. have subsequently proposed expanding the traditional 5point to a 10-point scale in order to improve the sensitivity of MMT [4]. The International Myositis Assessment and Clinical Trials Group (IMACS) and the Pediatric Rheumatology Clinical Trials Organization (PRINTO) have incorporated the Kendall scale as a core outcome measure for therapeutic trials [5, 6]. Nonetheless, the complexity of a 10-point scale may be an impediment to its widespread use in daily clinical practice.

A Rash analysis [7] performed to investigate physicians' ability to discriminate among the MRC-5 scale categories demonstrated a poor inter-individual reproducibility since physicians have limited discriminating abilities in this 5-grade system, raising the possibility that a more complex 10 categories scale might be even less reliable. In addition, floor and ceiling effects associated with these metrics have also been a major concern $[8,9]$.

In addition, MMT and other isometric muscle strength assessments do not reflect muscle endurance which is also an important component of patients' disability. Muscle strength and endurance are indeed two distinct components of muscle function as the first refers to the force-generating capacity of the muscle whereas the latter refers to the muscle's ability to sustain a specific task over time [10]. A non-linear relationship between strength and motor ability has been observed in several muscular disorders [11-13] and it has been suggested that functional capacity might be more closely related to muscle endurance than to muscle strength [10]. More recently, a functional scale - the Functional Index-2 (FI-2) - based on repetitive movements was developed to capture decreased muscle endurance in myositis [14]. Yet, its use in daily clinical practice may be limited by its performance time (up to 33 minutes).

Other simple muscle endurance and functional tests have been used routinely by clinicians for decades, such as the Barré and Mingazzini maneuvers (see description below) $[15,16]$, and evaluating the functional capacity to perform chair rise, crossinglegs and squatting. Of note, the Barré and Mingazzini tests have been originally developed to evaluate the pyramidal tract, nonetheless they have also been more recently included in some validated functional scores such as the Myasthenic Muscle Score [17] and the Childhood Myositis Assessment Scale [18] in order to assess both muscle strength and endurance. These tests are of particular interest since they target proximal muscle groups which are selectively involved in most myositis patients. However, their usefulness and responsiveness to change have never been reported in a cohort of myositis patients.

Our objective was therefore to compare the responsiveness to change of MMT, endurance and functional testing in the evaluation of myositis patients in daily clinical practice following induction therapy.

\section{MATERIAL AND METHODS}

\section{Study design}

This study was performed at our national reference center for neuromuscular diseases and patients were identified through a national myositis database. Prospectively recorded data (clinical - including MMT and functional tests - serological and 
histological) for each patient visit were retrospectively analyzed.

\section{Patient selection}

Patients were included if they had a diagnosis of dermatomyositis (DM) or immune-mediated necrotizing myopathy (IMNM) according to the ENMC criteria $[19,20]$, or an overlap myositis (OM), including antisynthetase syndrome (ASS) or connective tissue disease (CTD) associated myositis [21, 22]. Patients were selected if they presented a severe myositis flare requiring high-dose corticosteroids (CS) $(\geq 1 \mathrm{mg} / \mathrm{kg} /$ day of prednisone) in combination with immunotherapy (immunosuppressant +/intravenous immunoglobulin (IVIg)). As standard immunosuppressive therapy has not been shown to improve inclusion-body myositis (IBM) patients [23], patients meeting Griggs's criteria [24] for definite or possible IBM were not included in this study.

\section{Muscle disease assessment}

Strength was assessed by MMT and graded by one of the participating clinicians (OB, YA, AR and $\mathrm{BH}$ ) using the MRC-5 scale [25]. The following muscle groups were routinely assessed: deltoid, biceps, triceps, psoas, gluteus medius, quadriceps, hamstrings and neck flexors.

Additional endurance evaluation included the following:

- Barré test: time in seconds (sec) during which patient can maintain his arms in flexion at a $90^{\circ}$ angle with completely extended elbows (Supplement material). The value is set to 240 if the duration exceeds $240 \mathrm{sec}$.

- Mingazzini test: time in sec during which patient can maintain the supine position, with legs bent 90 degrees at the hip as well at the knees (Supplement material). The value is set to 100 if the duration exceeds $100 \mathrm{sec}$.

- Chair rises over $60 \mathrm{sec}$ : evaluated using standard armless chair with seat height of $45 \mathrm{~cm}$ found in the outpatient clinic and the patient was asked to repeatedly stand-up from a sitting position as many times as possible over $60 \mathrm{sec}$. A score of 0 was given if the patient was unable to perform the task.
Additional functional evaluation included the following:

- Chair rise capacity: evaluated using standard armless chair with seat height of $45 \mathrm{~cm}$ found in the outpatient clinic and the patient was asked to rise without using hands.

- Leg-crossing capacity: evaluated by asking the patient to cross legs without using hands.

- Squatting capacity: evaluated by asking the patient to bend his knees and hips at a $90^{\circ}$ angle.

\section{End points}

The clinical evolution of all muscle features was assessed at a mean of $6.4 \pm 1.9$ months after treatment intensification. Responsiveness to change, i.e responsiveness of scales/maneuvers to detect clinical change, was evaluated using Standardized Response Mean (SRM) and Standardized Mean Difference (SMD) between baseline and follow-up for each muscle groups presenting $a \leq 4 / 5$ muscle weakness at baseline.

\section{Statistical analysis}

Baseline characteristics for each myositis subgroups were compared using Chi-Square and Mann-Whitney tests. Muscle testing evolution from baseline to follow-up was correlated using Spearman correlation. SRM was computed by dividing the mean score change by the standard deviation of the change; SMD was computed by dividing the difference in the means between measurements points by the baseline standard deviation for the group. SRM and $\mathrm{SMD}<0.5,0.5-0.8$ and $>0.8$ were respectively considered as mild, moderate and strong differences. Categorical variables are reported as numbers and/or percentages and quantitative variables are reported as mean (SD). MMT is reported as median (range). Values of MMT at baseline and follow-up were compared using Wilcoxon signed-rank or MacNemar's test. A $p$-value below 0.05 was considered significant. All analyses were performed using SAS software v9.4 (Cary, NC, USA).

\section{Ethics statement}

The study was approved by the Pitié-Salpêtrière Ethics Committee and patients were reported anonymously according to French law. Written informed consent was obtained from each study patient to 
use medical information recorded in the myositis database for scientific purposes.

\section{RESULTS}

\section{Patients characteristics at baseline}

Fourty-nine patients were included with a diagnosis of DM $(n=11), \operatorname{IMNM}(n=21)$ and OM $(n=17$; including 9 ASS and 8 CTD-associated myositis) (Table 1). Seventy-one percent of patients were female and mean age at diagnosis was $45.8 \pm 16.8$ years. As per inclusion criteria all patients had muscle weakness, $47 \%$ had dysphagia and mean creatine kinase (CK) level was 5951 $\pm 10969 \mathrm{IU} / \mathrm{L}$ $(1195 \pm 1534 \mathrm{IU} / \mathrm{L}, 5106 \pm 3697 \mathrm{IU} / \mathrm{L}$ and $10072 \pm 17$ $546 \mathrm{IU} / \mathrm{L}$ in DM, IMNM and OM subsets, respectively). All patients received high-dose CS, 73\% in combination with IVIg and all patients had an immunosuppressant, most frequently methotrexate or azathioprine. Median muscle strength at baseline was: $4(3.0,4.0)$ in the deltoids, $3(2.0,4.0)$ in the psoas and $3(2.0,4.0)$ in the neck flexors (Table 2$)$. Mean Barré test was $110.4 \pm 92.7 \mathrm{sec}$, Mingazzini test was $26.3 \pm 32.9 \mathrm{sec}$ and chair-rise/min was $14.4 \pm 10.2$. On average, $47 \%$ of patients were able to perform chair-rise, $36 \%$ were able to perform legcrossing and $36 \%$ were able to squat. Endurance and functional testing across each subset are described in Table 2.

\section{Clinical evolution at follow-up}

Mean follow-up assessment was performed at $6.4 \pm 1.9$ months and $51 \%$ of patients had persistent proximal muscle weakness, none had dysphagia and mean CK level was $229 \pm 331$ IU/L. Median MMT was: $5(5.0,5.0)$ in the deltoids, $5(4.0,5.0)$ in the psoas and $4.5(4.0,5.0)$ in the neck flexors. All endurance maneuvers were improved with a mean Barré test of $190 \pm 67 \mathrm{sec}$, a Mingazzini test of $59 \pm 36$ $\mathrm{sec}$ and a chair-rise/min of $22 \pm 9$. Improvement of

Table 1

Patient's characteristics at baseline

\begin{tabular}{|c|c|c|c|c|c|}
\hline & $\begin{array}{l}\text { Overall } \\
(n=49)\end{array}$ & $\begin{array}{c}\mathrm{DM} \\
(n=11)\end{array}$ & $\begin{array}{l}\text { IMNM } \\
(n=21)\end{array}$ & $\begin{array}{c}\mathrm{OM} \\
(n=17)\end{array}$ & $p$-value \\
\hline \multicolumn{6}{|l|}{ Demographics } \\
\hline Gender, female, $\%$ & 71 & 91 & 67 & 65 & 0.27 \\
\hline Mean age at diagnosis, yrs & 45.8 & 47.5 & 47.3 & 43.1 & 0.71 \\
\hline Caucasian, $\%$ & 71 & 82 & 67 & 71 & 0.84 \\
\hline Disease duration, yrs & 2.3 & 1.4 & 3.3 & 1.6 & 0.10 \\
\hline \multicolumn{6}{|l|}{ Clinical features } \\
\hline Muscle weakness, $\%$ & 100 & 100 & 100 & 100 & \\
\hline Dysphagia, $\%$ & 47 & 55 & 43 & 47 & 0.82 \\
\hline Raynaud phenomenon, $\%$ & 31 & 0 & 35 & 47 & 0.029 \\
\hline Arthritis, $\%$ & 12 & 0 & 0 & 29 & 0.01 \\
\hline Interstitial lung disease, $\%$ & 21 & 10 & 15 & 35 & 0.2 \\
\hline \multicolumn{6}{|l|}{ Laboratory findings } \\
\hline MSA or MAA aAbs, $\%$ & 69 & & & & \\
\hline - DM-specific Abs, \% & 8 & 36 & 0 & 0 & 0.0005 \\
\hline - Anti-HMGCR Abs, \% & 10 & 0 & 24 & 0 & 0.024 \\
\hline - Anti-SRP Abs, $\%$ & 28 & 0 & 65 & 0 & $<0.001$ \\
\hline - Anti-Jo1 Abs, \% & 16 & 0 & 0 & 47 & $<0.001$ \\
\hline Mean CK level, IU/L & 5951 & 1195 & 5106 & 10072 & 0.10 \\
\hline \multicolumn{6}{|l|}{ Treatment } \\
\hline Corticosteroids ( $1 \mathrm{mg} / \mathrm{kg} / \mathrm{d})$ and/or pulses, $\%$ & 100 & 100 & 100 & 100 & \\
\hline Plasma exchange, $\%$ & 18 & 9 & 29 & 12 & 0.27 \\
\hline Intravenous immunoglobulin, $\%$ & 73 & 82 & 86 & 53 & 0.06 \\
\hline Methotrexate, \% & 43 & 45 & 43 & 41 & 0.98 \\
\hline Azathioprine, $\%$ & 31 & 36 & 29 & 29 & 0.89 \\
\hline Mycophenolate mofetil, \% & 14 & 0 & 10 & 29 & 0.07 \\
\hline Rituximab, \% & 22 & 9 & 29 & 24 & 0.45 \\
\hline Cyclophosphamide, $\%$ & 12 & 9 & 5 & 24 & 0.20 \\
\hline Ciclosporine, $\%$ & 2 & 9 & 0 & 0 & 0.17 \\
\hline
\end{tabular}

$\overline{\mathrm{DM}}=$ dermatomyositis; IMNM = immune-mediated necrotizing myopathy; $\mathrm{OM}=$ overlap myositis; yrs = years; $d=$ day; MSA=myositis-specific antibody; MAA=myositis-associated antibody; $\mathrm{CK}=$ creatine kinase. 
Table 2

Muscle, endurance and functional testing at baseline

\begin{tabular}{lccccc}
\hline & $\begin{array}{c}\text { Overall } \\
(n=49)\end{array}$ & $\begin{array}{c}\text { DM } \\
(n=11)\end{array}$ & $\begin{array}{c}\text { IMNM } \\
(n=21)\end{array}$ & $\begin{array}{c}\text { OM } \\
(n=17)\end{array}$ & $p$-value \\
\hline MRC scale, median (range) & & & & & \\
Shoulder abduction - Right & $4.0(3.0,4.0)$ & $4.0(2.0,5.0)$ & $4.0(1.0,5.0)$ & $4.0(0.0,5.0)$ & 0.57 \\
Shoulder abduction - Left & $4.0(3.0,5.0)$ & $4.0(1.0,5.0)$ & $4.0(1.0,5.0)$ & $4.0(0.0,5.0)$ & 0.64 \\
Elbow flexion - Right & $4.0(4.0,5.0)$ & $4.0(4.0,5.0)$ & $4.0(3.0,5.0)$ & $4.0(3.0,5.0)$ & 0.73 \\
Elbow flexion - Left & $4.0(4.0,5.0)$ & $4.0(4.0,5.0)$ & $4.0(2.0,5.0)$ & $4.0(3.0,5.0)$ & 0.87 \\
Hip flexion - Right & $3.0(2.0,4.0)$ & $4.0(3.0,5.0)$ & $2.0(1.0,4.0)$ & $3.0(1.0,5.0)$ & 0.002 \\
Hip flexion - Left & $3.0(2.0,4.0)$ & $4.0(3.0,5.0)$ & $2.0(1.0,4.0)$ & $3.5(1.0,5.0)$ & 0.002 \\
Hip abduction - Right & $4.0(3.0,5.0)$ & $4.0(3.0,5.0)$ & $3.5(1.0,5.0)$ & $4.0(2.0,5.0)$ & 0.05 \\
Hip abduction - Left & $4.0(3.0,4.0)$ & $4.0(3.0,5.0)$ & $3.5(1.0,5.0)$ & $4.0(2.0,5.0)$ & 0.038 \\
Knee extension - Right & $5(4.0,5.0)$ & $5.0(4.0,5.0)$ & $5.0(1.0,5.0)$ & $4.0(1.0,5.0)$ & 0.80 \\
Knee extension - Left & $5(4.0,5.0)$ & $5.0(4.0,5.0)$ & $5.0(1.0,5.0)$ & $4.0(1.0,5.0)$ & 0.55 \\
Knee flexion - Right & $4.0(4.0,5.0)$ & $4.0(4.0,5.0)$ & $4.0(1.0,5.0)$ & $4.0(1.0,5.0)$ & 0.37 \\
Knee flexion - Left & $4.0(4.0,5.0)$ & $4.0(4.0,5.0)$ & $4.0(1.0,5.0)$ & $4.0(1.0,5.0)$ & 0.37 \\
Neck flexion & $3(2.0,4.0)$ & $4.0(2.0,5.0)$ & $3.0(1.0,5.0)$ & $4.0(1.0,5.0)$ & 0.012 \\
Endurance testing & & & & & \\
Barré test, sec & $110.4(92.7)$ & $112.6(93.1)$ & $111.6(99.5)$ & $107.2(89.2)$ & 0.99 \\
Mingazzini test, sec & $26.3(32.9)$ & $44.5(33.8)$ & $11.3(24.3)$ & $34.1(35.2)$ & 0.014 \\
Chair rise count, \#/min & $14.4(10.2)$ & $15(10.5)$ & $13(11.5)$ & $16.2(8.3)$ & 0.69 \\
Functional evaluation & & & & & 0.08 \\
Chair rise capacity, \% & 47 & 70 & 20 & 64 & 0.043 \\
Leg-crossing capacity, \% & 36 & 60 & 17 & 79 & 0.55 \\
Squatting capacity,\% & 36 & 60 & 37 & 79 \\
DM cerman
\end{tabular}

$\mathrm{DM}=$ dermatomyositis; IMNM = immune-mediated necrotizing myopathy; $\mathrm{OM}=$ overlap myositis.

functional capacities was seen in $43 \%$ of patients for chair-rise, $49 \%$ patients for leg-crossing and $49 \%$ of patients for squatting.

\section{Responsiveness to change analyses}

Mean MMT, SMD and SRM at follow-up are reported in Table 3. Strong sensitivity to change $(\mathrm{SRM}>0.8)$ was observed in the muscle testing of the psoas, the deltoids, the biceps and the neck flexors. Strong sensitivity to change was also observed in all endurance tests, namely Barré test (SRM 1.05, $p<0.001$ ), Mingazzini test (SRM 0.96, $p<0.001$ ) and chair rise count (SRM 0.85, $p<0.001$ ). An improvement of all functional evaluations was also observed. On the other hand, the weakest sensitivity to change was observed in the quadriceps $(\mathrm{SRM}=0.57, p=0.002)$. Finally, a strong correlation was found between both the right and the left side of each of the muscle groups tested (Appendix). Yet, a poor correlation was observed between endurance tests and the muscle groups required to achieve its positioning (ex: Barré test and deltoids; Mingazzini test and psoas/quadriceps). Although some patients had a stable MMT between baseline and follow-up, we observed an amplitude variability in the Barré and Mingazzini tests (Table 4).

\section{DISCUSSION}

In the present study, we demonstrate that functional and endurance testing provides reliable, simple and complementary information to MMT in the assessment of myositis patients.

To date, poor attention has been given to muscle function and endurance and they are not included in the IMACS core set measures. Yet, the Childhood Myositis Assessment Scale (CMAS) has incorporated a 14-item that include physical function and endurance in juvenile myositis [18] and Alexandersson et al. have also described the FI- 2 in adult myositis [14]. Maximum performance time of FI-2 currently limits its use in daily practice, though a shortened version has been under validation [26]. Of note, a 1-kg weight-cuff and a $25 \mathrm{~cm}$ high stool are also required to perform some of the tasks.

In this study, we report the responsiveness to change of MMT using the MRC-5 scale and both functional and endurance testing in a cohort of welldefined active myositis patients following induction therapy. As expected, strongest responsiveness to change in the muscle testing was observed in the deltoids and psoas, but interestingly also in the Barré test. A strong SRM ( $>0.80)$ was also reported in most of the other muscle groups, except for the quadriceps, 
Table 3

Responsivess to change at follow-up assessment

\begin{tabular}{|c|c|c|c|c|c|}
\hline & $n$ & $\begin{array}{l}\text { Delta of mean } \\
\text { improvement }\end{array}$ & SMD & SRM & $p$-value \\
\hline \multicolumn{6}{|l|}{ MRC scale } \\
\hline Shoulder abduction - Right & 45 & 1.11 & 0.94 & 1.16 & $<0.001$ \\
\hline Shoulder abduction - Left & 45 & 1.07 & 0.84 & 1.03 & $<0.001$ \\
\hline Elbow flexion - Right & 45 & 0.58 & 0.85 & 0.88 & $<0.001$ \\
\hline Elbow flexion - Left & 45 & 0.67 & 0.89 & 0.90 & $<0.001$ \\
\hline Hip flexion - Right & 45 & 1.18 & 1.03 & 1.17 & $<0.001$ \\
\hline Hip flexion - Left & 45 & 1.18 & 1.00 & 1.23 & $<0.001$ \\
\hline Hip abduction - Right & 36 & 0.75 & 0.70 & 0.80 & $<0.001$ \\
\hline Hip abduction - Left & 36 & 0.78 & 0.75 & 0.81 & $<0.001$ \\
\hline Knee extension - Right & 41 & 0.51 & 0.55 & 0.61 & 0.002 \\
\hline Knee extension - Left & 41 & 0.54 & 0.57 & 0.57 & 0.002 \\
\hline Knee flexion - Right & 39 & 0.69 & 0.74 & 0.80 & $<0.001$ \\
\hline Knee flexion - Left & 39 & 0.77 & 0.82 & 0.88 & $<0.001$ \\
\hline Neck flexion & 41 & 0.95 & 0.79 & 0.85 & $<0.001$ \\
\hline \multicolumn{6}{|l|}{ Muscle enzyme } \\
\hline CK level & 48 & -5629.63 & -0.50 & -0.51 & $<0.0001$ \\
\hline \multicolumn{6}{|l|}{ Endurance testing } \\
\hline Barré test & 44 & 77.23 & 0.82 & 1.05 & $<0.001$ \\
\hline Mingazinni test & 43 & 33.14 & 0.99 & 0.96 & $<0.001$ \\
\hline \multirow[t]{2}{*}{ Chair rise count } & 30 & 7.27 & 0.74 & 0.85 & $<0.001$ \\
\hline & $n$ & $\%$ Worse & $\%$ Stable & $\%$ Improve & $p$-value \\
\hline \multicolumn{6}{|l|}{ Functional evaluation } \\
\hline Chair rise capacity & 42 & 0 & 57 & 43 & $<0.0001$ \\
\hline Leg-crossing capacity & 35 & 3 & 48 & 49 & 0.0001 \\
\hline Squatting capacity & 39 & 7 & 44 & 49 & 0.0009 \\
\hline
\end{tabular}

Wilcoxon's test for paired measures and MacNemar's test for pourcentages was used. ES = effect size; $\mathrm{SRM}=$ standardized response mean; $\mathrm{CK}=$ creatine kinase.

Table 4

Amplitude variability of endurance testing in patients with stable proximal muscle testing between $\mathrm{M} 0$ and follow-up assessment

\begin{tabular}{lccc}
\hline & $n$ & Mean $\Delta$ Barré (SD) & Mean $\Delta$ Mingazzini (SD) \\
\hline MRC scale & & & \\
Shoulder abduction - Right & 12 & $39.95(53.14)$ & NA \\
Shoulder abduction - Left & 14 & $36.35(46.97)$ & NA \\
Hip flexion - Right & 10 & NA & $21.60(36.96)$ \\
Hip flexion -Left & 11 & NA & $13.63(24.63)$ \\
\hline
\end{tabular}

$\Delta=$ delta variability, $\mathrm{SD}=$ standard deviation, $\mathrm{NA}=$ not applicable.

but also in all other endurance testing (Mingazzini test and chair rise count).

To our knowledge, standards for Barré and Mingazzini tests have never been defined. Upper limit cut-off used in our study for these endurance maneuvers (240 sec for Barré and $100 \mathrm{sec}$ for Mingazzini) may have underestimated results in stronger patients. Motivation, cooperation and pain during endurance testing may also affect its assessment. Yet, these behavioral factors may also affect MMT assessment.

Interestingly, as a non-linear correlation between muscle strength and endurance has previously been reported [23], the subgroup analysis of patients presenting stable MMT at follow-up demonstrated an improvement on endurance maneuvers. MRC is an ordinal scale and poor discriminatory ability may fail to capture intermediate variation within two steps. Moreover, endurance testing may help to overcome its ceiling effect [27].

One strength of our study is the inclusion of myositis patients at diagnosis or during relapse, making SRM assessment following induction therapy readily available. Moreover, we report detailed SRM in all muscle groups performed routinely in daily clinical practice in our medical center. Yet, since these assessments were performed as part of routine clinical care, physicians were not blinded and may have compared their assessment to previous scores. 
Moreover, the physician operating the MMT, endurance and functional maneuvers was not identified in the data collection, therefore intra- and inter-reliability were not computed. Nonetheless, the multiplicity of operators may have triggered an increased variability thereby negatively influencing our responsiveness analyses. Sharshar et al. has reported a high agreement between observers for the Myasthenic Muscle Score [28], which include the Barré and Mingazzini maneuvers. Nevertheless, even in the absence of standardization and in this real-life clinical setting we observe strong responsiveness to change in all endurance maneuvers.

Muscle weakness has previously been reported to be symmetric in myositis patients [29, 30]. Our correlational analyses also confirm these findings both at baseline (Table 2) and at follow-up (Appendix). Poor correlation between Barré test and deltoids, and Mingazzini test and psoas/quadriceps, suggest that endurance testing may be an independent and complementary variable in the evaluation of myositis patients. Nonetheless, despite these promising findings, interest of endurance testing need to be confirmed in myositis as well as other neuromuscular conditions.

Interestingly, triaxial wrist-worn accelerometer has recently been reported as a promising tool for assessing physical activity expenditure in myositis [31], may help capture muscle endurance component in daily life activities and may potentially become an attractive biomarker by providing an objective and reliable monitoring that is not limited by floor or ceiling effects [32].

Assessment of a few select proximal muscle groups (deltoids/psoas) combined with some functional and endurance (Barré/Mingazzini) testing is a simple, time-saving and reliable way to assess active myositis patients (except IBM) in daily clinical practice. Muscle endurance is independent from MMT, has an interest in the evaluation of patients with stable MMT, help overcome MMT's ceiling effect and should be evaluated as an outcome measure in myositis clinical trials.

\section{ACKNOWLEDGMENTS}

None.

\section{FUNDING}

This research did not receive any specific grant from funding agencies in the public, commercial, or not-for-profit sectors.

\section{DISCLOSURE}

Dr. Landon-Cardinal is the recipient of Clinical Fellowship awards from the Université de Montréal Rheumatology Program - Abbvie Educational Grant and the Association des médecins rhumatologues du Québec - Visithan-Khy Educational Grant. HD, NC, $\mathrm{KM}, \mathrm{AR}, \mathrm{BH}, \mathrm{YA}$ and $\mathrm{OB}$ report no disclosure.

\section{CONFLICT OF INTEREST}

The authors have no conflict of interest to report.

\section{SUPPLEMENTARY MATERIAL}

The supplementary material is available in the electronic version of this article: http://dx. doi.org/10.3233/JND-180358.

\section{REFERENCES}

[1] Huber AM, Rennebohm RM, Maillard SM. Assessing muscle strength, endurance and function. In: Rider, LG.; Pachman, LM.; Miller, FW.; Bollar, H., editors. Myositis and You: A Guide to Juvenile Dermatomyositis for Patients, Families and Healthcare Providers. Washington DC: The Myositis Association; 2007. pp. 139-52.

[2] Medical Research Council. Aids to the investigation of the peripheral nervous system. London: Her Majesty's Stationary Office; 1943.

[3] Dyck PJ, Boes CJ, Mulder D, Millikan C, Windebank AJ, Dyck PJ, et al. History of standard scoring, notation, and summation of neuromuscular signs. A current survey and recommendation. J Peripher Nerv Syst. 2005;10:158-73.

[4] Kendall FP, McCreary EK, Provance PG: Muscles: Testing and Function Baltimore, MD: Williams \& Wilkins; 1993.

[5] Rider LG, Giannini EH, Harris-Love M, Joe G, Isenberg D, Pilkington C, et al. Defining Clinical Improvement in Adult and Juvenile Myositis. J Rheumatol. 2003;30(3):603-17.

[6] Ruperto N, Ravelli A, Murray KJ, Lovell DJ, AnderssonGare B, Feldman BM, et al. Preliminary core sets of measures for disease activity and damage assessment in juvenile systemic lupus erythematosus and juvenile dermatomyositis. Rheumatology (Oxford). 2003;42(12):1452-9.

[7] Vanhoutte EK, Faber CG, van Nes SI, Jacobs BC, van Doorn PA, van Koningsveld R, et al. Modifying the Medical Research Council grading system through Rasch analyse. Brain. 2012;135(Pt 5):1639-49.

[8] Benveniste O, Rider L et al. 213th ENMC International Workshop: Outcome measures and clinical trial readiness in idiopathic inflammatory myopathies, Neuromuscul Dis. 2016;26:523-34.

[9] Rider LG, Werth VP, Huber AM, et al. Measures of adult and juvenile dermatomyositis, polymyositis, and inclusion body myositis: Physician and patient/parent global activity, manual muscle testing (MMT), Health Assessment Questionnaire (HAQ)/Childhood Health Assessment Questionnaire (C-HAQ), Childhood Myositis Assessment Scale (CMAS), Myositis Disease Activity Assessment Tool 
(MDAAT), Disease Activity Score (DAS), Short Form 36 (SF-36), Child Health Questionnaire (CHQ), physician global damage, Myositis Damage Index (MDI), quantitative muscle testing (QMT), Myositis Functional Index-2 (FI-2), Myositis Activities Profile (MAP), Inclusion Body Myositis Functional Rating Scale (IBMFRS), Cutaneous Dermatomyositis Disease Area and Severity Index (CDASI), Cutaneous Assessment Tool (CAT), Dermatomyositis Skin Severity Index (DSSI), Skindex, and Dermatology Life Quality Index (DLQI). Arthritis Care Res. 2011;63(suppl 11):S118S57.

[10] Nyberg A, Tornberg A, Wadell K. Correlation between Limb Muscle Endurance, Strength, and Functional Capacity in People with Chronic Obstructive Pulmonary Disease. Physiother Can. 2016;68(1):46-53.

[11] Lindeman E, Leffers P, Reulen J, Spaans F, Drukker J. Quadriceps strength and timed motor performances in myotonic dystrophy, Charcot-Marie-Tooth disease, and healthy subjects. Clin Rehabil. 1998;12:127-35.

[12] Servais L, Deconinck N, Moraux A, Benali M, Canal A. Van Parys F, et al. Innovative methods to assess upper limb strength and function in non-ambulant Duchenne patients. Neuromuscul Disord 2013;23:139-48.

[13] Hogrel JY, Allenbach Y, Canal A, Leroux G, Ollivier G, Mariampillai K, et al. Four-year longitudinal study of clinical and functional endpoints in sporadic inclusion body myositis: Implications for therapeutic trials. Neuromuscul Disord. 2014;24(7):604-10.

[14] Alexanderson H, Broman L, Tollback A, Josefson A, Lundberg IE, Stenstrom $\mathrm{CH}$. Functional Index-2: Validity and Reliability of a Disease-Specific Measure of Impairment in Patients With Polymyositis and Dermatomyositis. Arthritis Rheum. 2006;55:114-22.

[15] Barré JA. Le signe de l'écartement des doigts. XXIVe Congrès des aliénistes et neurologistes, Rev Neurol. 1920:942.

[16] Mingazzini G. Sur quelques «petits signes » des parésies organiques. Rev Neurol. 1913;20:469-473.

[17] Gajdos P, Sharshar T, Chevret S. Standards of measurements in myasthenia gravis. Ann N Y Acad Sci. 2003;998:445-52.

[18] Lovell DJ, Lindsley CB, Rennebohm RM, Ballinger SH, Bowyer SL, Giannini EH, et al. Development of disease activity and damage indices for the juvenile idiopathic inflammatory myopathies. II. The Childhood Myositis Assessment Scale (CMAS): A quantitative tool for the evaluation of muscle function. Arthritis Rheum. 1999;42:2213-9.

[19] Hoogendijk JE, Amato AA, Lecky BR, Choy EH, Lundberg IE, Rose MR, et al. 119th ENMC international workshop: Trial design in adult idiopathic inflammatory myopathies, with the exception of inclusion body myositis, 10-12 October 2003, Naarden, The Netherlands. Neuromuscul Disord. 2004;14(5):337-45.

[20] Allenbach Y, Mammen AL, Benveniste O, Stenzel W; Immune-Mediated Necrotizing Myopathies Working Group. 224th ENMC International Workshop: Clinico-seropathological classification of immune-mediated necrotizing myopathies Zandvoort, The Netherlands, 14-16 October 2016. Neuromuscul Disord. 2018;28:87-99.
[21] Troyanov Y, Targoff IN, Tremblay JL, Goulet JR, Raymond Y, Senécal JL. Novel classification of idiopathic inflammatory myopathies based on overlap syndrome features and autoantibodies: Analysis of 100 French Canadian patients. Medicine (Baltimore). 2005;84(4):231-49.

[22] Benveniste O, Stenzel W, Allenbach Y. Advances in serological diagnostics of inflammatory myopathies. Curr Opin Neurol. 2016;29(5):662-73.

[23] Benveniste O, Guiguet M, Freebody J, Dubourg O, Squier $\mathrm{W}$, Maisonobe T, et al. Long-term observational study of sporadic inclusion body myositis. Brain. 2011;134(Pt 11):3176-84.

[24] Griggs RC, Askanas V, DiMauro S, Engel A, Karpati G, Mendell JR, et al. Inclusion body myositis and myopathies. Ann Neurol. 1995;38:705-13.

[25] Compston A. Aids to the investigation of peripheral nerve injuries. Medical Research Council: Nerve Injuries Research Committee. His Majesty's Stationery Office: 1942; pp. 48 (iii) and 74 figures and 7 diagrams; with aids to the examination of the peripheral nervous system. By Michael O'Brien for the Guarantors of Brain. Saunders Elsevier; 2010. pp. [8] 64 and 94 Figures. Brain 2010; 133:2838-44.

[26] Ernste F, Alexanderson H, Ytterberg S, Reed A. Validation of the Functional Index 3 in polymyositis and dermatomyositis. Arthritis Rheumatol Suppl. 2012;S324.

[27] Amici DR, Pinal-Fernandez I, Pagkatipunan R, Mears A, De Lorenzo R, Tiniakou E et al. Muscle endurance deficits in myositis patients despite normal manual muscle testing scores. Muscle Nerve. 2018.

[28] Sharshar T, Chevret S, Mazighi M, Chillet P, Huberfeld G, Berreotta $\mathrm{C}$, et al. Validity and reliability of two muscle strength scores commonly used as endpoints in assessing treatment of myasthenia gravis. J Neurol. 2000;247(4):28690.

[29] Rider LG, Koziol D, Giannini EH, Jain MS, Smith MR, Whitney-Mahoney K, et al. Validation of Manual Muscle Testing and a Subset of Eight Muscles (MMT8) for Adult and Juvenile Idiopathic Inflammatory Myopathies. Arthritis Care Res (Hoboken). 2010;62(4):465-72.

[30] Harris-Love MO, Shrader JA, Koziol D, Pahlajani N, Jain M, Smith M, et al. Distribution and severity of weakness among patients with polymyositis, dermatomyositis and juvenile dermatomyositis. Rheumatology (Oxford). 2009;48(2):134-9.

[31] Bachasson D, Landon-Cardinal O, Benveniste O, Hogrel JY, Allenbach Y. Physical activity monitoring: A promising outcome measure in idiopathic inflammatory myopathies. Neurology. 2017;89(1):101-03.

[32] Dimachkie MM, Paganoni. Outcome measures in the idiopathic inflammatory myopathies: On the search for the holy grail. Neurology. 2017;89(1):20-21. 


\section{APPENDIX}

\begin{tabular}{|c|c|c|c|c|c|c|c|c|c|c|c|c|c|c|c|c|c|}
\hline $\begin{array}{l}\text { MRC } \\
\text { scale }\end{array}$ & $\begin{array}{c}\mathrm{r} \text { with } \\
\text { Deltoid R }\end{array}$ & $\begin{array}{c}\mathrm{r} \text { with } \\
\text { Deltoid L }\end{array}$ & $\begin{array}{c}\mathrm{r} \text { with } \\
\text { Biceps R }\end{array}$ & $\begin{array}{c}\mathrm{r} \text { with } \\
\text { Biceps L }\end{array}$ & $\begin{array}{c}\mathrm{r} \text { with } \\
\text { Psoas R }\end{array}$ & $\begin{array}{c}\mathrm{r} \text { with } \\
\text { Psoas L }\end{array}$ & $\begin{array}{l}\mathrm{r} \text { with } \\
\text { GM R }\end{array}$ & $\begin{array}{l}\mathrm{r} \text { with } \\
\text { GM L }\end{array}$ & $\begin{array}{c}\mathrm{r} \text { with } \\
\text { Quads R }\end{array}$ & $\begin{array}{c}\mathrm{r} \text { with } \\
\text { Quads L }\end{array}$ & $\begin{array}{l}\text { r with } \\
\text { HS R }\end{array}$ & $\begin{array}{l}\text { r with } \\
\text { HS L }\end{array}$ & $\begin{array}{c}\mathrm{r} \text { with } \\
\mathrm{NF}\end{array}$ & $\begin{array}{l}\mathrm{r} \text { with } \\
\text { Barre }\end{array}$ & $\begin{array}{l}\mathrm{r} \text { with } \\
\text { Minga }\end{array}$ & $\begin{array}{c}\mathrm{r} \text { with } \\
\text { Chair rise }\end{array}$ & $\begin{array}{c}\mathrm{r} \text { with } \\
\text { CK level }\end{array}$ \\
\hline$\overline{\text { Deltoid R }}$ & 1.00 & 0.91 & 0.40 & 0.34 & 0.46 & 0.50 & 0.35 & 0.31 & 0.37 & 0.37 & 0.60 & 0.60 & 0.19 & 0.49 & 0.29 & 0.69 & -0.44 \\
\hline Deltoid L & 0.93 & 1.00 & 0.38 & 0.36 & 0.46 & 0.56 & 0.46 & 0.45 & 0.44 & 0.38 & 0.56 & 0.57 & 0.04 & 0.46 & 0.36 & 0.69 & -0.44 \\
\hline Biceps R & 0.40 & 0.38 & 1.00 & 0.83 & 0.14 & 0.22 & 0.08 & 0.01 & 0.43 & 0.45 & 0.26 & 0.36 & 0.04 & 0.23 & 0.08 & 0.13 & -0.34 \\
\hline Biceps L & 0.34 & 0.36 & 0.83 & 1.00 & 0.06 & 0.20 & 0.19 & 0.16 & 0.47 & 0.47 & 0.25 & 0.39 & 0.01 & 0.10 & -0.10 & 0.02 & -0.30 \\
\hline Psoas R & 0.46 & 0.46 & 0.14 & 0.06 & 1.00 & 0.91 & 0.41 & 0.43 & 0.11 & 0.17 & 0.34 & 0.32 & 0.37 & 0.24 & 0.36 & 0.40 & -0.33 \\
\hline Psoas L & 0.50 & 0.56 & 0.22 & 0.20 & 0.91 & 1.00 & 0.49 & 0.50 & 0.20 & 0.23 & 0.28 & 0.29 & 0.22 & 0.34 & 0.46 & 0.39 & -0.36 \\
\hline Gluteus medius $\mathrm{R}$ & 0.35 & 0.46 & 0.08 & 0.19 & 0.41 & 0.49 & 1.00 & 0.95 & 0.00 & -0.16 & 0.34 & 0.22 & 0.25 & 0.27 & 0.09 & 0.37 & 0.09 \\
\hline Gluteus medius L & 0.31 & 0.45 & 0.01 & 0.16 & 0.43 & 0.50 & 0.95 & 1.00 & -0.02 & -0.13 & 0.24 & 0.13 & 0.24 & 0.22 & 0.14 & 0.46 & 0.08 \\
\hline Quadriceps R & 0.37 & 0.44 & 0.43 & 0.47 & 0.11 & 0.20 & 0.00 & -0.02 & 1.00 & 0.93 & 0.59 & 0.67 & 0.07 & 0.10 & 0.00 & 0.45 & -0.49 \\
\hline Quadriceps L & 0.37 & 0.38 & 0.45 & 0.47 & 0.17 & 0.23 & -0.16 & -0.13 & 0.93 & 1.00 & 0.55 & 0.62 & 0.06 & 0.03 & 0.02 & 0.44 & -0.45 \\
\hline Hamstrings $\mathrm{R}$ & 0.60 & 0.56 & 0.26 & 0.25 & 0.34 & 0.28 & 0.34 & 0.24 & 0.59 & 0.55 & 1.00 & 0.95 & 0.49 & 0.27 & 0.05 & 0.56 & -0.49 \\
\hline Hamstrings L & 0.60 & 0.57 & 0.36 & 0.39 & 0.32 & 0.29 & 0.22 & 0.13 & 0.67 & 0.62 & 0.95 & 1.00 & 0.40 & 0.23 & 0.03 & 0.52 & -0.47 \\
\hline Neck flexion & 0.19 & 0.04 & 0.04 & 0.01 & 0.37 & 0.22 & 0.25 & 0.24 & 0.07 & 0.06 & 0.49 & 0.40 & 1.00 & 0.16 & 0.08 & 0.21 & -0.16 \\
\hline Barré test & 0.49 & 0.46 & 0.23 & 0.10 & 0.24 & 0.34 & 0.27 & 0.22 & 0.10 & 0.03 & 0.27 & 0.23 & 0.16 & 1.00 & 0.38 & 0.34 & -0.17 \\
\hline Mingazzini test & 0.29 & 0.36 & 0.08 & -0.10 & 0.36 & 0.46 & 0.09 & 0.14 & 0.00 & 0.02 & 0.05 & 0.03 & 0.08 & 0.38 & 1.00 & 0.41 & -0.08 \\
\hline Chair rise count & 0.69 & 0.69 & 0.13 & 0.02 & 0.40 & 0.39 & 0.37 & 0.46 & 0.45 & 0.44 & 0.56 & 0.52 & 0.21 & 0.34 & 0.41 & 1.00 & -0.38 \\
\hline CK level & -0.44 & -0.44 & -0.34 & -0.30 & -0.33 & -0.36 & 0.09 & 0.08 & -0.49 & -0.45 & -0.49 & -0.47 & -0.16 & -0.17 & -0.08 & -0.38 & 1.00 \\
\hline
\end{tabular}

$\mathrm{R}=$ right; $\mathrm{L}=$ left; $\mathrm{GM}=$ gluteus medius; Quads = quadriceps; $\mathrm{HS}=$ hamstring; $\mathrm{NF}=$ neck flexion; Minga = mingazinni; $\mathrm{CK}=$ creatine kinase. 